\title{
DISTRIBUSI SPASIO-TEMPORAL POPULASI RAJUNGAN (Portunus pelagicus) BETINA MENGERAMI TELUR DI PERAIRAN PESISIR LAMPUNG TIMUR
}

\author{
SPATIAL TEMPORAL DISTRIBUTION OF PORTUNUS PELAGICUS (Portunus \\ pelagicus) BREEDING POPULATION IN COASTAL WATERS OF EAST LAMPUNG
}

\author{
Zairion, Yusli Wardiatno, Achmad Fahrudin, Mennofatria Boer \\ Dosen pada Fakultas Perikanan dan Ilmu Kelautan, Institut Pertanian Bogor \\ Teregistrasi I tanggal: 11 Maret 2014; Diterima setelah perbaikan tanggal: 05 Agustus 2014; \\ Disetujui terbit tanggal: 08 Agustus 2014 \\ E-mail:zairion.zai@gmail.com
}

\begin{abstract}
ABSTRAK
Distribusi spasio-temporal populasi rajungan betina yang mengerami telur (BEF) telah dikaji di perairan pesisir Lampung Timur. Penelitian dilakukan pada tiga stratifikasi kedalaman perairan: $<5 \mathrm{~m}$ (strata S1), antara 5-10 m (strata S2), dan >10 m (strata S3) serta empat sub-area (A1-A4) di setiap stratum dari bulan Maret 2012-Februari 2013. Kelimpahan populasi rajungan BEF diindikasikan dengan proporsi rajungan BEF/betina tidak mengerami telur (NBF) dan BEF/total individu. Perbedaan proporsi dianalisis dengan uji ANOVA satu arah. Hasil penelitian menunjukan bahwa proporsi rajungan BEF bervariasi secara spasial, ditemukan mulai dari strata S1 dan meningkat ke strata S3. Daerah pemijahan dan pembiakan yang dominan terdapat pada kedalaman air $>5 \mathrm{~m}$ dan di sub-area A2 dan A3. Secara agregat, BEF ditemukan sepanjang tahun dengan dua puncak kelimpahan (Mei dan September-Oktober) sebagai puncak musim pemijahan dan pembiakan. Proporsi rajungan BEF secara spasio-temporal tumpang tindih dengan daerah penangkapan rajungan pada hampir semua musim. Diperlukan strategi pengelolaan pemanfataan yang sesuai untuk menunjang keberhasilan reproduksi, diantaranya penangkapan menggunakan alat yang dapat mempertahankan BEF dalam keadaan hidup selama terperangkap, kemudian melepaskannya atau memeliharanya di area tertentu sampai menetaskan telurnya sehingga dapat meningkatkan produksi larva dan pada akhirnya dapat mempertahankan populasi dan stok.
\end{abstract}

Kata Kunci: Rajungan, betina mengerami telur, Lampung Timur

\section{ABSTRACT}

Spatial-temporal distribution of berried females (BEFs) Portunus pelagicus was studied in East Lampung coastal waters. An investigation was conducted at three water depth stratifications, i.e., less than $5 \mathrm{~m}$ (stratum S1), between 5-10 m (stratum S2) and more than $10 \mathrm{~m}$ (stratum S3), as well as four sub-areas (A1-A4) in each of stratifications from March 2012 to February 2013. The abundance of BEF population was indicated by their proportion to non-berried females (NBFs) and to the total individual crabs, while the differences among the results were tested by one-way ANOVA test. The results showed that the proportions of BEFs varied spatially, increased from stratum S1 to S3. Spawning and breeding seemed to dominantly occur at water depth more than $5 \mathrm{~m}$ and $A 2$ and $A 3$ sub-areas. BEFs were found throughout the year with two peaks of its occurrence, i.e. in May and in September to October, and those months were considered as peak of spawning and breeding seasons. The spatial and temporal occurrence of BEFs overlapped with crab fishing grounds in most fishing seasons. An appropriate fisheries management strategy is required for their reproduction success. Capturing crab by using eco-friendly fishing gear that render caught BEFs alive and releasing them or keeping them in certain area for hatching their eggs would enhance larvae production to maintain population and stock.

Keywords: Blue swimming crab, breeding population, East Lampung

\section{PENDAHULUAN}

Informasi distrubusi spasio-temporal dan struktur populasi sumber daya rajungan, Portunus pelagicus (Brachyura: Portunidae) sangat diperlukan sebagai dasar pengelolaan (Kangas, 2000). Sementara itu distribusi rajungan betina yang mengerami telur (berried females atau ovigerous females, $B E F$ ) sebagai bagian dari karakter nisbah kelamin merupakan bagian penting dalam analisis struktur populasi (Dixon \& Hooper, 2010). Keberadaan

Korespondensi penulis:

Fakultas Perikanan dan Ilmu Kelautan, Institut Pertanian Bogor

Jl. Lingkar Akademik, Kampus IPB-Darmaga, Bogor rajungan BEF sebagai populasi betina yang akan menetaskan telur dan melahirkan larva (breeding population) menjadi salah satu faktor kunci dalam menunjang kelangsungan reproduksi, rekrutmen dan menjamin keberlanjutan stok. Kelimpahan rajungan BEF pada periode tertentu dikenal sebagai musim pembiakan atau breeding season (Rasyeed \& Mustaquim, 2010), dan dapat menjadi indikator musim pemijahan (Svane \& Bryars, 2005). Hal ini disebabkan oleh fertilisasi terjadi secara eksternal dan telur yang dibuahi menempel pada 
pleopod betina hingga menetas. Masa inkubasi telur yang dibuahi memerlukan waktu sekitar 8 hari pada temperatur dan salinitas air masing-masing antara $26-27^{\circ} \mathrm{C}$ dan 30-32 PSU (Arsyad et al., 2006).

Salah satu perairan pesisir yang potensial sebagai daerah penangkapan rajungan di Indonesia adalah Lampung Timur dan umumnya diusahakan dalam perikanan skala kecil dengan alat tangkap yang dominan adalah jaring insang dasar (set gill-net). Produksi rajungan di daerah ini cenderung meningkat dalam kurun waktu 10 tahun terakhir, namun terjadi penurunan produktivitas penangkapannya (Wardiatno \& Zairion, 2011). Hal ini ditengarai oleh kelebihan tangkap (over fished) dan penurunan produktivitas stok yang dapat mengganggu keberlanjutan perikanan rajungan.

Informasi biologi, ekologi serta status stok rajungan masih sedikit diperoleh di daerah ini. Penelitian untuk mengidentifikasi dearah pemijahan (spawning ground) rajungan sudah dilakukan, namun belum dapat dideskripsikan secara memadai daerah dan puncak musim pemijahannya (Wardiatno \& Zairion, 2011). Kajian biologi reproduksi dan pendataan proporsi rajungan hasil tangkapan yang didaratkan (terutama rajungan BEF) menunjukan puncak musim pemijahan di perairan Lampung timur berlangsung antara bulan April-Juni dan OktoberNovember (Zairion et al., 2014a). Kendatipun demikian kajian tersebut belum mencakup analisis spasial rajungan BEF dan variasi musim pemijahan berdasarkan pola kehadirannya.

Tulisan ini bertujuan untuk mengetahui variasi populasi rajungan betina mengerami telur (BEF) berdasarkan lokasi (spasial), waktu dan/atau musim (temporal) di perairan pesisir Lampung Timur. Hasil penelitian diharapkan sebagai informasi dasar status sumber daya rajungan dan menjadi bahan masukan untuk pengelolaan pemanfaatannya secara berkelanjutan.

\section{BAHANDANMETODE Pengumpulan Data}

Pengumpulan data hasil tangkapan dan tingkat kematangan gonad rajungan dilakukan setiap bulan Maret 2012-Februari 2013 di perairan pesisir Lampung Timur pada posisi geografis antara $4^{\circ} 42^{\prime}-5^{\circ} 25^{\prime}$ LS dan $105^{\circ} 48^{\prime}-106^{\circ} 10^{\prime}$ BT. Penelitian didisain menurut stratifikasi kedalaman perairan (adaptasi Bryars \& Havenhand, 2004). Berdasarkan isodepth pada peta laut Indonesia nomor 68 dan 104 (Dishidros TNI AL, 2003), yaitu: bentang area perairan dengan kedalaman $<5 \mathrm{~m}$ (strata $\mathrm{S} 1)$, antara 5"10 m (strata S2), >10 m (strata S3) (Gambar 1). Berdasarkan jaraknya dari garis pantai, ketiga stratifikasi ini mewakili jalur penangkapan ikan I (0-4 mil laut), II (4-12 mil laut), dan III sesuai dengan Permen Kelautan dan Perikanan
Republik Indonesia No. 18/PerMenKp/2013. Selanjutnya ditetapkan empat sub-area (A1-A4) di setiap strata berdasarkan karakteristik morfologi dan vegetasi pantai di sratum 1. Sub-area A1 merupakan perairan pantai di sebelah timur kawasan konservasi hutan dataran rendah (Taman Nasional Way Kambas-TNWK) dengan karakteristik pantai adalah lumpur berpasir dan mempunyai formasi mangrove yang tebal dari garis pantai ke arah daratan. Sub-area A2 mendapat masukan air tawar dari sungai kecil (Way Kambas) yang berasal dari dalam wilayah TNWK, sedangkan sub-area A3 mendapat masukan air tawar juga dari sungai kecil (Way Penet) yang berada di perbatasan sebelah selatan TNWK Kedua sub area tersebut meliputi hutan mangrove tipis. Pantai di subarea A4 mempunyai vegetasi yang minim dan pemanfaatan untuk pertambakan, persawahan, permukiman, dan pangkalan pendaratan ikan (PPI) di Kuala Penet serta Pelabuhan Perikanan Pantai (PPP) di Labuhan Maringgai.

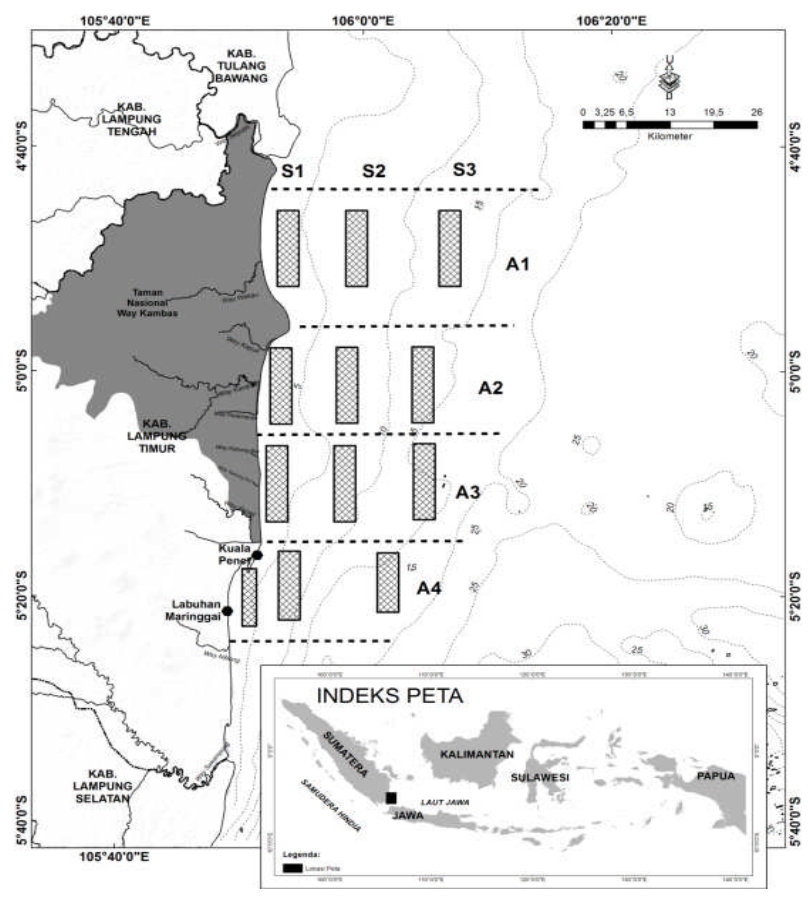

Gambar 1. Peta pantai timur Lampung dan posisi area pengambilan contoh rajungan pada bulan Maret 2012-Februari 2013.

(Keterangan: S1-S3 = stratifikasi kontur kedalaman perairan; A1-A4, area yang di arsir = sub-area pengambilan contoh)

Figure 1. Map of east coast of Lampung and the position of the blue swimming crab sampling during March 2012 to Februari 2013.

(Remarks: $\quad$ 1-S3 = bathymetric stratifications; $A 1-A 4$, shade in areas $=s u b$ area sampling site) 
Tabel 1. Koordinat acuan posisi pengambilan contoh rajungan pada bulan Maret 2012-Februari 2013

Table 1. Geographic point of reference for the blue swimming crab sampling during March 2012 to Februari 2013

\begin{tabular}{|c|c|c|c|c|c|}
\hline No. & Kode lokasi & Posisi geografis acuan & No. & Kode lokasi & Posisi geografis acuan \\
\hline 1 & S1-A1 & $\begin{array}{l}4^{\circ} 49^{\prime} 31,1^{\prime \prime} \mathrm{LS} ; \\
105^{\circ} 53^{\prime} 50,6^{\prime \prime} \mathrm{BT}\end{array}$ & 7 & S2-A3 & $\begin{array}{l}5^{\circ} 09^{\prime} 49,3^{\prime \prime} \mathrm{LS} \\
105^{\circ} 58^{\prime} 25,2^{\prime \prime} \mathrm{BT}\end{array}$ \\
\hline 2 & S1-A2 & $\begin{array}{l}5^{\circ} 00^{\prime} 30,7 " \mathrm{LS} \\
105^{\circ} 53^{\prime} 44,1^{\prime \prime} \mathrm{BT}\end{array}$ & 8 & S2-A4 & $\begin{array}{l}5^{\circ} 19^{\prime} 39,8^{\prime \prime} \mathrm{LS} \\
105^{\circ} 55^{\prime} 57,0^{\prime \prime} \mathrm{BT}\end{array}$ \\
\hline 3 & S1-A3 & $\begin{array}{l}5^{\circ} 09^{\prime} 51,5^{\prime \prime} \mathrm{LS} \\
105^{\circ} 52^{\prime} 58,2^{\prime \prime} \mathrm{BT}\end{array}$ & 9 & S3-A1 & $\begin{array}{l}4^{\circ} 49^{\prime} 15,2^{\prime \prime ~ L S} \\
106^{\circ} 05^{\prime} 42,8^{\prime \prime} \mathrm{BT}\end{array}$ \\
\hline 4 & S1-A4 & $\begin{array}{l}5^{\circ} 19^{\prime} 43,6^{\prime \prime} \mathrm{LS} \\
105^{\circ} 51^{\prime} 4,1^{\prime \prime} \mathrm{BT}\end{array}$ & 10 & S3-A2 & $\begin{array}{l}5^{\circ} 00^{\prime} 8,9^{\prime \prime} \text { LS; } \\
106^{\circ} 05^{\prime} 33,4^{\prime \prime} \text { BT }\end{array}$ \\
\hline 5 & S2-A1 & $\begin{array}{l}4^{\circ} 49^{\prime} 3,6^{\prime \prime} \mathrm{LS} \\
106^{\circ} 00^{\prime} 20,8^{\prime \prime} \mathrm{BT}\end{array}$ & 11 & S3-A3 & $\begin{array}{l}5^{\circ} 09^{\prime} 46,6^{\prime \prime} \mathrm{LS} \\
106^{\circ} 04^{\prime} 17,5^{\prime \prime} \mathrm{BT}\end{array}$ \\
\hline 6 & S2-A2 & $\begin{array}{l}5^{\circ} 00^{\prime} 23,0^{\prime \prime} \mathrm{LS} ; \\
105^{\circ} 59^{\prime} 59,2^{\prime \prime} \mathrm{BT}\end{array}$ & 12 & S3-A4 & $\begin{array}{l}5^{\circ} 18^{\prime} 6,0^{\prime \prime} \mathrm{LS} ; \\
106^{\circ} 03^{\prime} 28,2^{\prime \prime} \mathrm{BT}\end{array}$ \\
\hline
\end{tabular}

Penangkapan rajungan dilakukan secara acak pada bentang area di setiap stratifikasi dan sub-area kajian (Gambar 1; area yang diarsir) dengan koordinat acuan seperti disajikan pada Tabel 1. Alat tanggkap yang digunakan adalah 3 unit jaring insang dasar (set gill-net) dengan tinggi 0,8 $\mathrm{m} \pm 0,09 \mathrm{SD}$ (8-9 mata) dan ukuran mata jaring (mesh size) antara 3,0-4,5 inci (7,6-11,4 cm). Kegiatan penangkapan rajungan dilakukan pada malam hari dengan waktu rata-rata jaring terendam (soaking period) $10 \mathrm{jam}$. Hasil tangkapan setiap unit jaring dihitung jumlah dan bobot total per-jenis kelamin, baik jantan (M), betina yang tidak mengerami telur atau non-BEF (NBF), maupun betina mengerami telur (BEF). Parameter lingkungan perairan adalah temperatur yang berasal dari interpretasi citra satelit NOAA dan dilengkapi dengan data pengecekan di lapangan (ground truth data collection). Parameter lingkungan lainnya adalah salinitas dan fraksi substrat dasar sedimen berdasarkan hasil penelitian sebelumnya (Zairion et al., 2014a).

\section{Analisis Data}

Dengan tinggi rata-rata jaring 0,8 $\mathrm{m} \pm 0,09 \mathrm{SD}$, daya kerut (hanging ratio) diasumsikan tidak berpengaruh secara signifikan, sehingga data hasil tangkapan distandarisasikan terhadap ukuran jaring terpanjang. Proporsi rajungan BEF merupakan persentase dari jumlah BEF/jumlah betina non-BEF (NBF) dan jumlah BEF/total individu, tidak termasuk bobot atau biomas. Analisis spasial dan temporal dilakukan secara deskriptif, yaitu kecenderungan proporsi BEF berdasarkan stratifikasi dan sub-area pengamatan setiap bulan dan/atau musim. Berdasarkan data dari Stasiun Klimatologi Maritim Lampung (2003-2012), periode musim barat/musim penghujan (termasuk musim peralihan II) dan musim timur/ musim kemarau (termasuk musim peralihan I) di Lampung Timur masing-masing berlangsung dari bulan OktoberMaret dan April-September. Untuk mengetahui perbedaan proporsi rajungan $\mathrm{BEF}$ secara spasial dan temporal dilakukan analisis sidik ragam satu faktor (one way analyses of variance, one way ANOVA) dengan tingkat kepercayaan 95\% (Fowler \& Cohen, 1992).

\section{HASIL DAN BAHASAN \\ HASIL}

Proporsi rajungan BEF/NBF umumnya meningkat dari strata S1 ke strata S3 dan puncaknya bervariasi pada setiap stratifikasi terhadap waktu pengamatan. Proporsi rajungan $\mathrm{BEF} / \mathrm{NBF}$ di strata S1 berkisar antara 0-21,98\% (rata-rata = $6,10 \%$ ) setiap bulan dan BEF selalu ditemukan di lokasi ini, kecuali pada bulan Januari (Gambar 2a). Sementara itu proporsi BEF/NBF di strata S2 berkisar antara 5,65-73,23\% (rata-rata $=26,05 \%$ ), tetinggi pada bulan Mei dan terendah pada bulan Maret. Tidak ada data di strata S3 pada bulan Agustus-September (akhir musim timur) dan OktoberNovember (awal musim barat) berhubung kondisi gelombang yang tinggi sehingga mempengaruhi kegiatan sampling dan kelimpahan rajungan juga sangat rendah. Proporsi BEF/NBF di lokasi ini (data delapan bulan) berkisar antara $8,67-50 \%$ (rata-rata $=24,67 \%$ ) dan dari data delapan bulan menunjukan bahwa proporsinya lebih tinggi di lokasi ini dibanding S2 pada bulan Februari-Mei dan Desember. Tampak juga bahwa proporsi rajungan BEF/ NBF (data gabungan dari strata S1 hingga S3 dan tanpa data di S3 pada bulan Agustus-November) selalu tinggi di setiap stratifikasi pada bulan Mei, September dan Oktober dibanding waktu lainnya. Rata-rata proporsi BEF/ NBF ini adalah 16,21\%.

Proporsi BEF/total individu setiap bulan di strata S1 berkisar antara 0-7,97\% (rata-rata $=2,47 \%$ ), sementara di strata S2 berkisar antara 2,64-17,82\% (rata-rata $=9,46 \%$ ) (Gambar 2b). Kecuali bulan Agustus-November, proporsi $\mathrm{BEF} /$ total individu di strata S3 berkisar antara 3,39-20,19\% (rata-rata $=9,18 \%$ ) dan rata-rata proporsi $\mathrm{BEF} /$ total individu dari S1-S3 (data gabungan) adalah 6,42\%. 

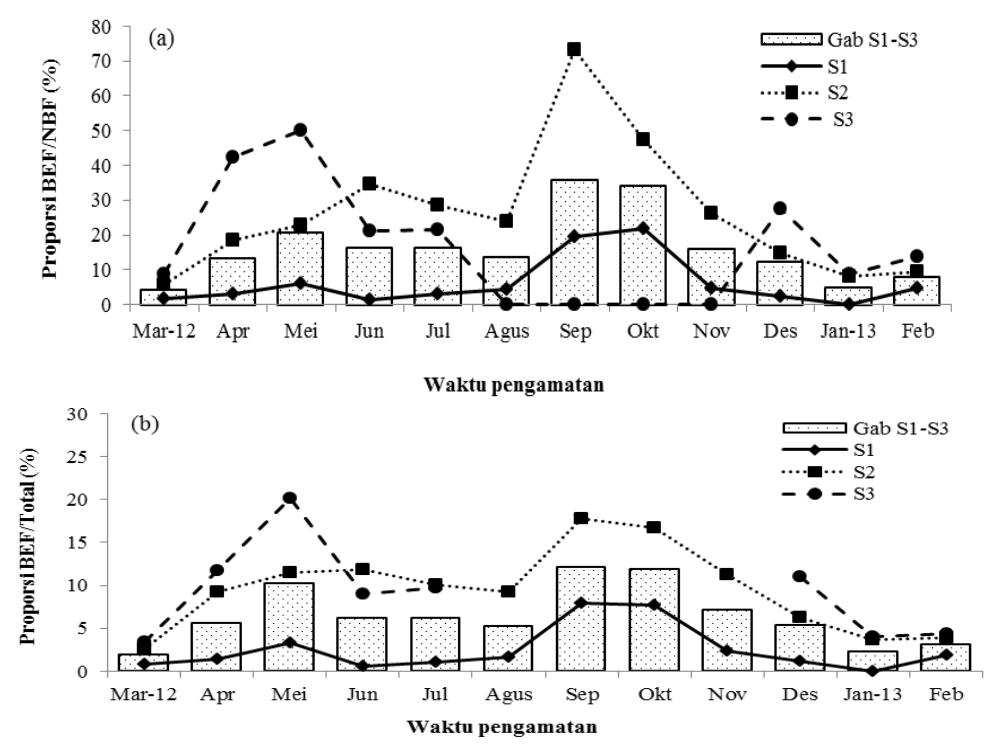

Gambar 2. Proporsi rajungan BEF menurut waktu penelitian pada setiap stratifikasi dan total area; (a) proporsi BEF/ $\mathrm{NBF}$, (b) proporsi BEF/ total individu.

Figure 2. The proportion of BEF by sampling period in each of observed stratifications and total area: (a) the proportion of BEF to $N B F,(b)$ the roportion of BEF to total individual crab.

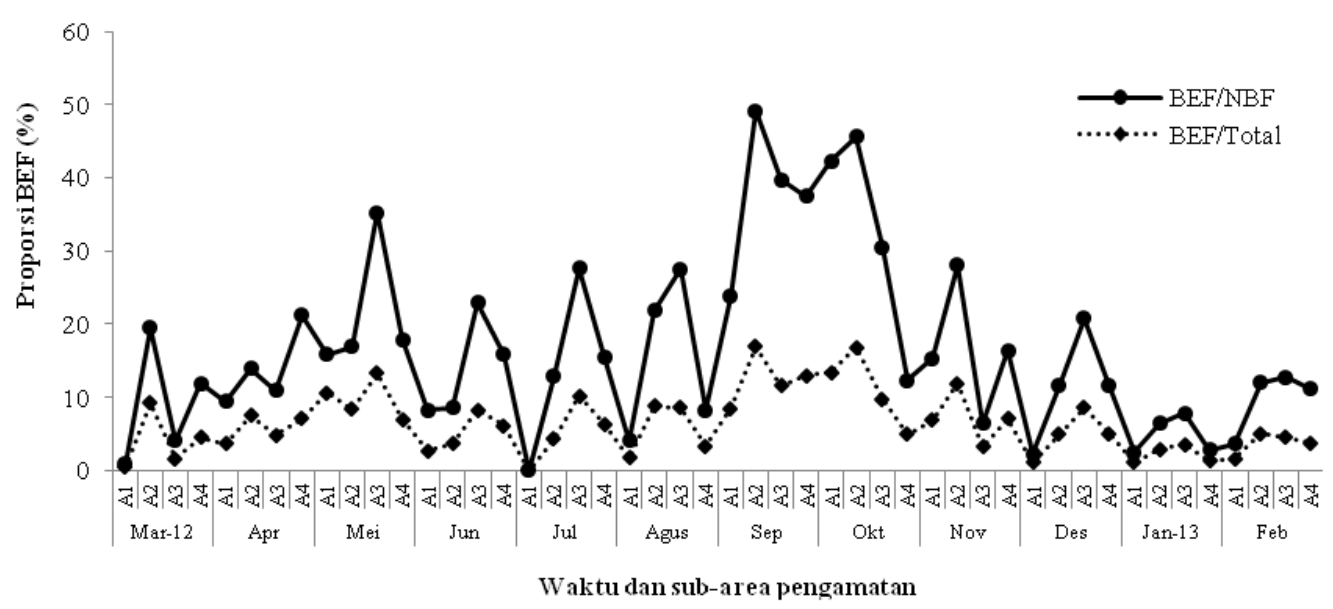

Gambar3. Proporsi rajungan BEF/NBF dan BEF/total individu pada setiap sub-area (A1-A4) menurut waktu pengamatan.

Figure 3. The proportion of BEF to NBF and BEF to total individual crab in each of observed sub-areas by month.

Mengingat ketersediaan data tidak kontinu di strata S3, maka uji perbedaan proporsi rajungan $\mathrm{BEF} / \mathrm{NBF}$ untuk seluruh periode waktu pengamatan hanya dilakukan antara S1 dengan S2. Hasilnya menunjukan berbeda nyata antar stratifikasi $\left(P_{1,10}=0,001 ; P<0,05\right)$. Untuk perbandingan antara S1 hingga S3 dilakukan berdasarkan data dari bulan Desember-Maret (mewakili periode musim barat) dan AprilJuli (periode musim timur), menunjukan bahwa proporsi BEF berbeda nyata antar stratifikasi $\left(P_{2,7}=0,02 ; P<0,05\right)$.

Proporsi BEF/NBF juga bervariasi berdasarkan subarea pengamatan (A1-A4). Proporsi di sub-area A1 lebih rendah dibanding sub-area lainnya pada setiap bulan pengamatan (Gambar 3). Proporsi BEF/NBF dominan di sub-area A2 pada bulan Maret, September dan OktoberNovember. Kecuali bulan Agustus-November, proporsi $\mathrm{BEF} / \mathrm{NBF}$ di sub-area A3 lebih tinggi dibanding sub-area lainnya pada bulan Mei-Juli (periode musim timur) dan Desember-Januari (musim barat). Proporsi BEF/NBF berbeda nyata antar sub-area $\left(P_{3,30}=0,001 ; P<0,05\right)$ dan waktu pengamatan $\left(P_{3,10}=0,00003 ; P<0,05\right)$. Pola yang hampir sama juga tampak pada proporsi $\mathrm{BEF} /$ total individu di masing-masing sub-area pengamatan. Baik BEF/NBF maupun $\mathrm{BEF} /$ total individu dominan ditemukan di subarea $\mathrm{A} 2$ dan $\mathrm{A} 3$. 


\section{BAHASAN}

Terjadinya variasi spasial dan temporal kelimpahan BEF diduga akibat beberapa faktor, diantaranya migrasi untuk memijah dan pergerakan (movement) rajungan. Kepiting suku portunidae (swimming crabs) bermigrasi untuk memijah ke perairan yang lebih dalam atau ke perairan yang mempunyai salinitas tinggi (Hill, 1994; Potter \& de Lestang, 2000; Kamrani et al., 2010; Anna et al., 2012). Ikhwanuddin et al. (2012) melaporkan bahwa di perairan pesisir yang kurang mendapat masukan air tawar, rajungan betina bermigrasi secara signifikan ke dua arah, yaitu ke perairan yang dangkal dan perairan yang dalam sejauh $5,33-12,8 \mathrm{~km}$ (rata-rata $=9,15 \mathrm{~km} \pm 1,87$ ) dalam kurun waktu 30 hari serta diduga untuk keperluan pemijahan. Selain itu, BEF juga melakukan pergerakan (movement) guna mencari lokasi yang baik untuk menetaskan telur, misalnya pada substrat berpasir (Kangas, 2000; Hamasaki \& Fukunaga, 2008) dan pergerakan ini mengikuti pola arus pasang surut atau circatidal rhythm (Carr et al., 2004; Forward Jr. et al., 2005). Dengan demikian, variasi keberadaan rajungan BEF secara spasial mengindikasikan daerah pemijahannya tersebar secara luas, mulai dari perairan pantai (kedalamam $<5$-m) hingga perairan yang lebih dalam (>10-m).

Hasil penelitian ini juga menunjukan bahwa pada strata S1 dengan kedalam perairan $<5 \mathrm{~m}$, umumnya ditemukan rajungan BEF setiap bulan dengan proporsi yang tinggi pada bulan September (akhir musim timur atau akhir musim kemarau) dan Oktober (awal musim barat atau musim penghujan). Temperatur air pada strata $\mathrm{S} 1$, baik pada musim hujan maupun kemarau berkisar antara $28-32 \%{ }^{\circ} \mathrm{C}$. Salinitas bagian dasar perairan berkisar antara 27-32 PSU pada musim kemarau dan tidak bervariasi besar dibanding musim penghujan (25-30 PSU). Sementara itu fraksi sedimen substrat dasar didominasi oleh lempung berpasir (Zairion et al., 2014a). Kondisi ini diduga dapat mendukung aktivitas pemijahan dan/atau pelepasan telur bagi rajungan $\mathrm{BEF}$, sehingga perairan pada strata $\mathrm{S} 1$ (kedalaman $<5-\mathrm{m}$ ) diperkirakan menjadi bagian dari daerah pemijahan, terutama pada puncak musim pemijahannya. Hasil penelitian ini sesuai dengan Nitiratsuwan et al. (2010), bahwa rajungan BEF banyak ditemukan di perairan pantai yang dangkal dan ekosistem lamun, yang mana perairannya minim mendapat masukan air tawar, sehingga diperkirakan memijah atau melepaskan telurnya di perairan tersebut.

Tingginya proporsi rajungan BEF pada strata S2 dibanding strata S1, termasuk strata S3 (data dari bulan Desember-Juli), maka daerah pemijahan dan sekaligus pembiakan rajungan diduga di perairan yang lebih dalam (kedalaman air $>5 \mathrm{~m}$ ). Hasil ini sesuai dengan pendapat Bryars \& Havenhand (2004), bahwa kelimpahan zoea I yang tinggi ditemukan pada hampir semua kolom air di perairan laut dengan kedalaman antara 10-15 m, sehingga pelepasan telur rajungan yang dierami atau penetasannya diduga terjadi pada perairan dengan kedalaman $>10 \mathrm{~m}$. Selain itu, salinitas perairan dasar di strata S2 dan S3 pada musim penghujan (musim barat) dan kemarau (musim timur) masing-masing berkisar antara 27-30 PSU dan 2932 PSU serta fraksi sedimen substrat dasar terdiri dari pasir berlempung, lempung berpasir dan pasir (Zairion et al., 2014a), sehingga sangat mendukung pemijahan dan/atau penetasan telur pada kedua strata ini. Rajungan betina dewasa yang tergolong reproduktif mempunyai ukuran lebar karapas antara 111-155,9 mm (Zairion et al. (2014b). Rajungan kelompok ini dominan tersebar pada perairan dengan kedalaman $>5 \mathrm{~m}$, sehingga memperkuat dugaan bahwa daerah pemijahan utama rajungan terdapat di perairan dengan kedalaman air $>5 \mathrm{~m}$.

Rajungan BEF ditemukan di seluruh sub-area pengamatan, terutama di A2 dan A3. Kedua area perairan ini mendapatkan masukan air tawar yang minim. Kondisi demikian diduga dapat mendukung keberadaan rajungan BEF. Terutama di sub-area A3, terdapat gundukan pasir (sand bank) yang tidak muncul ke permukaan air dan dikenal oleh nelayan lokal sebagai Gosong Padamaran (ditunjukan oleh bathymetri yang menonjol ke arah laut pada Gambar 1). Lokasi ini diduga sebagai daerah yang disukai oleh rajungan $\mathrm{BEF}$, karena merupakan daerah tangkapan dengan proporsi BEF yang tinggi. Daerah ini diduga sebagai daerah pemijahan atau pelepasan telur rajungan, terutama pada bulan Juni-September (musim timur) dan Oktober-November (musim barat). Hal yang sama juga terdapat di sub-area A3 pada kedalaman >10-m (strata S3). Hasil tangkapan rajungan di daerah ini sering didominasi oleh proporsi BEF yang tinggi, terutama pada bulan April-Mei (musim timur) dan Desember-Maret (musim barat). Diduga perairan ini juga merupakan daerah pemijahan atau pelepasan telurnya. Pemijahan dan sekaligus penetasan telur diperkirakan juga terjadi di perairan yang lebih dalam dan berada di luar wilayah kajian, mengingat distribusi rajungan mencapai kedalaman air 50 $\mathrm{m}(\mathrm{Ng}, 1998)$. Pada kajian ini belum dapat didukung oleh data ukuran rajungan betina non-BEF dan proporsi rajungan BEF yang tertangkap pada kedalaman air antara 20-50 m.

Secara agregat, rajungan BEF ditemukan sepanjang tahun dan berbeda secara nyata berdasarkan waktu pengamatan, sehingga mengindikasikan pola pemijahan bersifat kontinu-musiman (seasonal continues). Puncak musim pemijahan terdapat pada bulan Mei dan September (awal dan akhir musim timur), serta bulan Oktober (awal musim barat). Hampir sama dengan yang dilaporkan oleh Batoy et al. (1987), bahwa rajungan di perairan Leyte (Filipina) memijah sepanjang tahun dengan dua musim puncaknya, yaitu pada kwartal pertama dan terakhir. Sementara itu, Ingles \& Bkaum (1989) juga melaporkan 


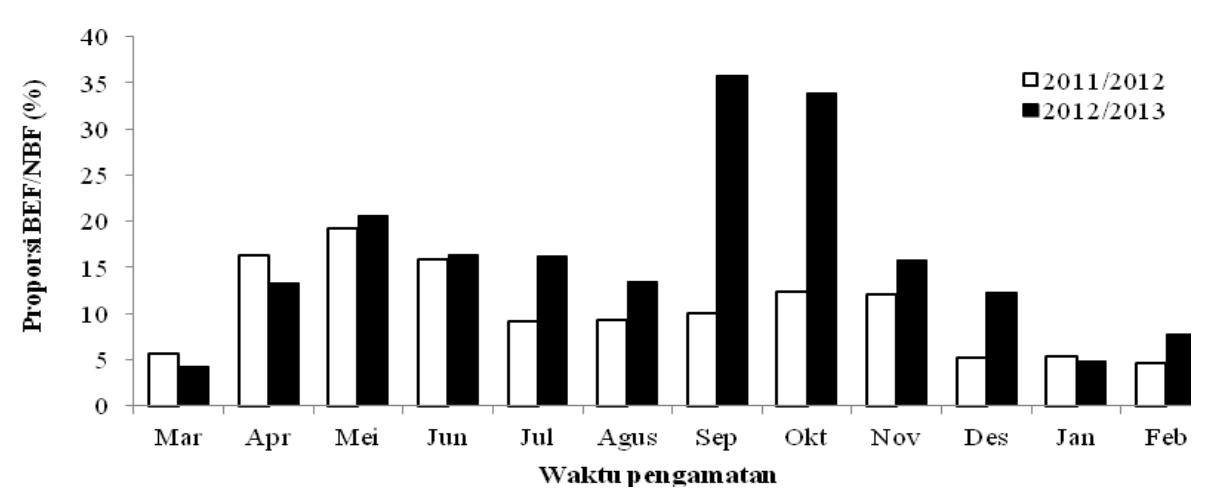

Gambar4. Perbandingan proporsi BEF/NBF setiap bulan pada tahun 2011/2012 (Zairion et al., 2014a) dan hasil pengamatan pada tahun 2012/2013. Pola pemijahan tampak sama, tetapi puncaknya sedikit berbeda.

Figure 4. Comparative proportion of BEF/NBF in each months in the year of 2012/2013 (Zairion et al., 2014a) and based on observation in the year of 2012/2013. Spawning seems to be the same pattern, but peak season slightly different.

bahwa puncak musim pemijahan rajungan di Teluk Ragay (Filipina) berlangsung pada bulan Februari-April dan JuliOktober.

Pola musim pemijahan rajungan yang diperoleh di lokasi ini adalah sama dengan hasil pengamatan pada tahun 2011/ 2012 (Zairion et al., 2014a), sedangkan puncaknya sedikit berbeda (Gambar 4). Diduga sebagai penyebabnya adalah perubahan iklim regional dengan indikasi rata-rata bulanan suhu permukaan laut (SST) pada musim kemarau (musim timur) tahun 2011 lebih rendah $1,5 \%{ }^{\circ} \mathrm{C}$ dibanding tahun 2012 (hasil interpretasi citra satelit NOAA). Perbedaan suhu yang terjadi tidak besar, namun demikian diperkirakan dapat mempengaruhi pemijahan rajungan. Peningkatan suhu perairan dapat mempercepat kematangan gonad dan pemijahan bagi rajungan muda (Fisher, 1999). Rajungan BEF yang ditemukan pada bulan September dan Oktober 2012 sebagian tergolong rajungan remaja dan dewasa yang kurang reproduktif, yaitu mempunyai ukuran lebar karapas <111 mm (Zairion et al., 2014b). Proporsi rajungan BEF kurang reproduktif ini masing-masing sekitar $29 \%$ dan $17 \%$ pada kedua bulan tersebut. Proporsi yang demikian tergolong tinggi dibanding periode lainnya.

Penangkapan rajungan di perairan pesisir Lampung Timur berlangsung sepanjang tahun dan daerah tangkapannya terwakili oleh wilayah kajian ini, termasuk proporsi rajungan BEF yang tertangkap. Dengan demikian daerah panangkapan hampir sama dengan daerah distribusi rajungan BEF. Selain itu, puncak musim penangkapan rajungan pada strata $\mathrm{S} 1-\mathrm{S} 3$ dan sub-area A1-A4 berlangsung selama lima bulan, yaitu dari Desember/ Januari hingga April/Mei, sehingga terdapat puncak musim penangkapan yang tumpah tindih dengan puncak musim pemijahan, yaitu bulan Mei. Penangkapan dapat dikategorikan sebagai musim sedang (Mei/Juni dan
Oktober/November-Desember) dan musim paceklik (JuliSeptember/Oktober). Kendatipun demikian penangkapan rajungan masih tumpang tindih dengan puncak musim pemijahan lainnya (misalnya September-Oktober). Berdasarkan kondisi ini, peluang tertangkapnya rajungan $\mathrm{BEF}$ adalah besar, karena intensitas penangkapan diduga tinggi. Diperkirakan rajungan BEF yang mempunyai peluang untuk lolos tertangkap adalah yang berada di luar daerah tangkapan dan proporsinya belum dapat diketahui dari kajian ini.

Rata-rata proporsi rajungan $\mathrm{BEF} / \mathrm{NBF}$ dan $\mathrm{BEF} /$ total individu yang tertangkap masing-masing adalah $16,21 \%$ dan $6,42 \%$. Proporsi tangkapan rajungan BEF yang demikian diduga tinggi, sehingga dapat menimbulkan recruitment overfishing. Pada penangkapan oleh nelayan, semua rajungan BEF yang tertangkap di jual ke pengumpul dan/atau industri pengolahan daging rajungan (mini plant). Untuk itu diperlukan strategi pengelolaan pemanfaatan yang sesuai, diantaranya menggunakan alat tangkap yang ramah lingkungan dan mampu mempertahan rajungan BEF dalam kondisi hidup selama terperangkap oleh alat tangkap (misalnya bubu lipat atau bubu tipe kubah). Rajungan BEF yang tertangkap dilepaskan kembali atau dipelihara oleh nelayan di suatu area perairan sampai melepaskan telurnya. Kedua alternatif di atas mempunyai tujuan untuk menunjang keberhasilan reproduksi dan meningkatkan produksi larva serta pada akhirnya akan dapat meningkatkan rekrutmen dan menjamin keberlanjutan populasi dan stok. Alternatif pertama dapat mempengaruhi penghasilan nelayan, sedangkan alternatif kedua tidak mengurangi nilai hasil tangkapannya, namun menundanya selama beberapa hari hingga satu minggu. Upaya ini memerlukan pendekatan komanajemen disertai dengan pengawasan dan pembinaan kepada nelayan penangkap rajungan. 


\section{KESIMPULAN}

Penelitian rajungan betina mengerami telur (BEF) di pantai timur Lampung diperoleh bahwa distribusi rajungan BEF bervariasi secara spasial. Proporsi tinggi terdapat pada kedalaman perairan $>5$-m pada daerah dengan subsrat dasar terdiri dari pesisir berlumpur dan pesisirnya ditumbuhi sedikit mangrove dan vegetasi pantai lainnya. Lokasi ini juga merupakan daerah untuk pemijahan dan pembiakannya. Rajungan BEF ditemukan sepanjang tahun dan berseptuasi menurut waktu dan musimnya. Puncak musim pemijahan dan pembiakan berlangsung pada bulan Mei (awal musim timur) dan September-Oktober (akhir musim timur dan awal musim barat). Secara umum daerah penangkapan rajungan berada pada daerah yang sama dengan rajungan yang menyuami telur. Diperlukan strategi pengelolaan perikanan rajungan dengan mempertimbangkan keberlanjutan reproduksi, rekruitmen dan ketersediaan stok rajungan. Disarankan penggunaan alat tangkap rajungan yang mampu mempertahan rajungan BEF dalam kondisi hidup selama terperangkap, kemudian melepaskannya kembali ke laut atau dipelihara oleh nelayan di suatu area perairan sampai rajungan tersebut menetaskan telurnya.

\section{PERSANTUNAN}

Penelitian ini didanai sebagian oleh Ditjen Dikti, Kementerian Pendidikan dan Kebudayaan Republik Indonesia dan bantuan dari Departemen MSP-FPIK. Penulis menghaturkan terima kasih kepada semua pihak atas segala bantuan moril dan materil selama pelaksanaan penelitian.

\section{DAFTAR PUSTAKA}

Anna, S., A. Turra \& F.J. Zarra. 2012. Reproductive migration and population dynamics of the blue crab Callinectes danae in an estuary in southeastern Brazil. Mar. Biol. Res., 8 (4): 354-362.

Arshad A, Efrizal, M.S. Kamarudin, \& C.R. Saad. 2006. Study on fecundity, embryology and larval development of blue swimming crab Portunus pelagicus (Linnaeus, 1758) under laboratory conditions. Research Journal of Fisheries and Hydrobiology. 1(1): 35-44.

Batoy, C.B., J.F. Sarmago, \& B.C. Pilapil. 1987. Breeding season, sexual maturity and fecundity of the blue crab, Portunus pelagicus L. in selected coastal waters in Leyte and vicinity, Philippines. Annals of Tropical Research, 93: 157-177.

Bryars, S.R. \& J.N. Havenhand. 2004. Temporal and spatial distribution of the blue swimming crab (Portunus pelagicus) larvae in temperate gulf. Marine and Freshwater Research 55: 805-818.

Carr, S. D., R.A. Tankersley, J.L. Hench, R.B. Forward Jr., \& R.A. Luettich Jr. 2004. Movement patterns and trajectories of ovigerous blue crab Callinectes sapidus during the spawning migration. Est. Coast. Shelf Sci 60: 567-579.

Dixon, C.D. \& G.E. Hooper. 2010. Blue swimming crab (Portunus armatus) 2009/2010. Stock assessment report to PIRSA Fisheries. South Australian Research and Development Institute (Aquatic science). Adelaide (AU): SARDI Publication No. F2007/000729-6, SARDI Report Series No. 428. 86pp.

Fisher, M.R. 1999. Effect of temperature and salinity on size at maturity of female blue crabs. Transactions of the American Fisheries Society 128 (3): 499-506.

Forward Jr., R.B., J.H. Cohen, M.Z. Darnell, \& A. Saal. 2005. The circatidal rhythm in vertical swimming of female blue crabs, Callinectes sapidus, during their spawning migration: A reconsideration. Journal of Shellfish Research 24 (2):587-590.

Fowler, J. \& L. Cohen. 1992. Practical statistics for field biology. John Wiley \& Sons Ltd. Chicester, England.

Hamasaki, K. \& K. Fukunaga. 2008. Ovipositional behaviour of the swimming crab, Portunus trituberculatus (Miers, 1876) (Decapoda, Portunidae): Implications for brood stock management in a hatchery: Crustaceana, 81 (7): 813-822.

Hill, B.J. 1994. Offshore spawning by the portunid crab Scylla serrate (Crustacea: Decapoda). Mar. Biol., 120: 379-384.

Ikhwanuddin, M., A.H. Nurfaseha, A.B. Abol-Monafi, \& M.L. Shabdin. 2012. Movement patterns of blue swimming crab, Portunus pelagicus in the Sarawak Coastal Water, South China Sea. Journal of Sustainability Science and Management. 7 (1) : 8-15.

Ingles, J.A. \& E. Bkaum. 1989. Reproduction and larval ecology of the blue swimming crab, Portunus pelagicus, in Ragay Gulf, Philippines. Int. Revue ges. Hydrobiol., 74: 471-490.

Kamrani, E., A.N. Sabili, \& M. Yahyavi. 2010. Stock assessment and reproductive biology of the blue swimming crab, Portunus pelagicus in Bandar Abbas coastal waters, Norther Persian Gulf. Journal of the Persian Gulf/Marine Science, 1(2):11-22. 
Kangas, M.I. 2000. Synopsis of the biology and exploitation of the blue swimmer crab, Portunus pelagicus Linnaeus, in Western Australia. Fisheries Western Australia, Perth, Western Australia. Fisheries Research Report No. 121.

Ng PKL. 1998. Crabs. In: The living marine resources of the Western Central Pacific, Volume 2: Cephalopods, Crustaceans, Holothurians and Sharks. Di dalam: Carpenter KE \& Niem VA (Editors). FAO Species Identification Guide For Fishery Purposes. Rome (IT): FAO of The United Nations. 1045-1146 (1115-1131).

Nitiratsuwan, T., C. Nitithamyong, S. Chiayvareesajja, \& B. Somboonsuke. 2010. Distribution of blue swimming crab (Portunus pelagicus Linnaeus, 1758) in Trang Province. Songklanakarin J. of Sci. and Tech., 32 (3): 207-212.

Potter, I.C. \& S. de Lestang S. 2000. Biology of the blue swimmer crab (Portunus pelagicus) in Leschenault Estuary and Koombana Bay, South Western Australia. J. Royal Soc. Western Australia, 83: 443-458.

Rasheed, S. \& J. Mustaquim. 2010. Size at sexual maturity, breeding season and fecundity of three-spot swimming crab Portunus sanguinolentus (Herbst, 1783) (Decapoda, Brachyura, Portunidae) occurring in the coastal waters of Karachi, Pakistan. Fisheries Research, 103: 56-62. doi:10.1016/j.fishres. 2010.02.002.
Svane, I. \& S. Bryars. 2005. Blue crab biology and key biological determinants important to the fishery, Chapter II, p. 26-59. In: Svane, I. \& A. Cheshire (Eds.). Fisheries biology and spatial modelling of the blue swimmer crab (Portunus pelagicus). SARDI Aquatic Sciences Publication No. RD98/0200-2, SARDI Research Report Series No. 117. 124p.

Wardiatno, Y. \& Zairion. 2011. Study on bioecology of the blue swimming crab and bioeconomic performance of crab fishery in order to propose of spawning ground protection [Report]. Indonesian Blue Swimming Crab Processing Association (APRI) in cooperation with Department of ARM-FFMS-IPB: 77p.

Zairion, Y. Wardiatno, \& A. Fahrudin. 2014a. Sexual maturity, reproductive pattern and spawning female population of the blue swimming crab, Portunus pelagicus (Brachyura: Portunidae) in East Lampung waters, Indonesia. Indian Journal of Sciences and Technology (submitted).

Zairion, Y. Wardiatno, M. Boer, \& A. Fahrudin. 2014b. Reproductive biology of the blue swimming crab, Portunus pelagicus (Brachyura: Portunidae) in East Lampung waters, Indonesia: Fecundity and reproductive potential. Tropical Life Sciences Research (submitted). 